\title{
THE HERPETOLOGY OF ST JOHN AND ADJACENT KEYS, U. S. VIRGIN ISLANDS
}

\author{
Chapman Grant, Major, U. S. Army.
}

The arid appearing little Island of St. John lies east of St. Thomas. There is no industry and practically no cultivation except where the scattered negro population tends patches of truck. Mountain trails connect the ruined Dutch manor houses, which flourished in the days of rum and slavery. Schools are plentiful and well attended. Cattle, horses and mongoose are much in evidence. The last has practically exterminated land turtles, ground lizards and snakes.

The principal incentive to visiting St. John, from April 13-17, 1932, was to try to enlarge the herpetological check list which Barbour limits to five species in "Zoologica", Vol. XI, No. 4, 1930. It is easy enough to assume what species probably occur on an Island, but there is greater satisfaction in actually collecting the specimens.

Barbour lists-1. Ameiva exsul; 2. Amphisbaena fenestrata; 3. Mabouia sloanii; 4. Alsophis antillensis, and 5. Dromicus exiguus only. Of these, M. sloanii should undoubtedly read $M$. semitaeniatus. I believe the former is confined to P. R. The latter has probably reached the verge of extermination on St. John, as I saw no specimens and the natives did not recognize a sample shown them from Culebra. They say that snakes are very rarely seen. Ameiva seems to be restricted to the neighborhood of the settlement at Cruz Bay, where the mongoose is kept off by the dogs.

The following is probably the latest and most complete list from this area:

1. Eleutherodactylus antillensis, (Reinhardt \& Lutken). Numerous under banana sheaths, sometimes in groups of eight or more.

Occasional specimens were found in the axils of bromeliads. The black loreal region and bright red eyes were prominent. The back is colored terra-cotta, tan, pink or rarely gray. The voice did not seem to differ greatly from the Puerto Rico specimens.

Specimens taken 72

2. Eleutherodactylus cochranae sp. nov.

It is described elsewhere in this number. They were found ex- 
clusively in the axils of bromeliads, together with a few E. antillensis. The voice was not heard.

\section{Leptodactylus albilabris (Gunther).}

Plentiful under rocks in the muddy ponds along dry stream beds. They have striking differences from their Puerto Rican counterparts. but closely resemble the St. Thomas topotypes, of which I took 7 specimens. It would appear that the P. R. species is different. The St. John species has the upper surface black, the throat heavily marked with black and the snout developed for burrowing, whereas the P. R. form is diversely colored above, white underneath. Many froth nests were found containing eggs and larvae.

Specimens taken 73

\section{Hemidactylus mabouia (Moreau de Jonnes).}

Found in frame buildings and under living banana sheaths. In this it shows a different habitat from $H$. brookii of P.R., which resorts to mortar or stone buildings. Known as "Wood slaves" to the natives.

Specimens taken 21

\section{Sphaerodactylus macrolepis Gunther}

These agree with specimens from St. Croix and Water Island, St. Thomas. The male has a gray body and "Target" pattern head. No red-head males seen, which further strengthens the validity of $S$. danforthi, of Culebra and Vieques. Numerous in favored places.

Specimens taken 22

6. Anolis cristatellus Dumeril \& Bibron

Numerous and showed no variation from those of St. Thomas, except that on Stephen Key the tail crest was extremely high. None of the highly patterned females was seen as on Puerto Rico. I believe two species are found together on Puerto Rico and are grouped as one.

Specimens taken 16

7. Anolis pulchellus Dumeril \& Bibron

Not numerous. The fan does not have the crimson center seen. on the Puerto Rico specimens. 
THE HERPETOLOGY OF ST. JOHN AND ADJACENT KEYS, V. I. 333

8. Anolis stratulus. Cope

Uncommon. Found from the mangroves at sea level to the hill tops. The fan is of a deeper yellow than on Puerto Rico.

Specimens taken 23

9. Ameiva exsul. Cope

This species is listed by Barbour. Numerous near the buildings at Cruz Bay where the dogs keep the mongoose away. No large specimens seen. Where the mongoose is numerous, large Ameivas are seldom seen. The natives say the "ground lizard" is found nowhere else on the island.

Specimens taken 19

10. Mabouia semitaeniatus. Wiegmann.

Not seen. Probably near extinction. This species is doubtless what occurred here, but is listed by Barbour as $M$. sloanii, which I believe occurs only on Puerto Rico. The natives did not recognize pictures of this species.

11. Amphisbaena fenestrata. Cope.

Not seen. Listed by Barbour. Doubtless numerous but there is so little cultivation that opportunities for taking it are few.

12. Typhlops jamaicensis (Shaw)

Two specimens sent me by Mr. B. E. Bauman may be referred to the above species pending a revision of the material from this area.

Specimens taken

2

13. Alsophis antillensis :(Schlegel)

Probably extinct on St. John. Two specimens taken on Dog Island. Said on good authority to occur on Lovango and Congo Keys.

Specimens taken (Dog Island) 2

14. Dromicus exiguus. Cope.

Not seen. Listed by Barbour. This is probably the species that is still occasionally seen by the natives. Probably occurs on the outlying keys as well.

15. Testudo tabulata.

Still occurs feral on Lovango Key and Water Island. There is excellent authority for including this species which was omitted by later writers. To be treated in another paper. 
334 THE JOURNAL OF THE DEPARTMENT OF AGRICULTURE OF P. R.

A group of three islets lies between St. Thomas and St. John, known from east to west as Dog Island, Little St. James and St. James.

Dog Island is the smallest, is treeless and absolutely carpeted with cactus, bearing the finest exhibit of Cactus intortus I have ever seen. Specimens taken:

1. Anotis cristatellus 2

2. Alsophis antillensis 2

Little St. James is much larger, has a few thickets and small trees and plenty of cactus and thorns. Specimens taken:

1. Sphaerodactylus macrolepis

2. Ameiva exsul

3. Anolis cristatellus_-_- 3

4. Anolis pulchellus___-_- 2

Northwest of St. John lie two narrow keys, Congo and Lovango, parallel and separated by a narrow channel. The former is a steep mass of diorite covered with trees and cactus. The latter is earth covered, grass grown and practically treeless.

Congo Key :

1. Sphaerodactylus macrolepis -_-_-_-_- 6

2. Anolis cristatellus_-_-_- 1

3. Anolis stratulus___-_-_-_ 3

Lovango Key:

1. Ameiva exsul_-_-_- 3

2. Anolis cristatellus___-_- 4

3. Anolis pulchellus__-_-_-_-_- 1

Excellent authority points to the occurrence of Testudo tabulata on Lovango and Alsophis on both keys. 